Jurnal_ep, Vol. 8 No. 2, Agustus 2018

\title{
PENGARUH PENERAPAN MODEL PEMBELAJARAN KOOPERATIF TIPE STUDENT TEAMS ACHIEVEMENT DIVISION (STAD) DAN BENTUK ASSESSMENT KINERJA TERHADAP KETERAMPILAN PROSES TIK UNTUK SISWA KELAS VIII DI SMP NEGERI 1 KUTA
}

\author{
Oleh \\ Kadek Ariek Kusuma Dewi, I Made Candiasa, Ni Ketut Widiartini \\ Program Studi Penelitian dan Evaluasi Pendidikan, Program Pascasarjana \\ Universitas Pendidikan Ganesha \\ Singaraja, Indonesia
}

e-mail: \{kusuma.dewi1,made.candiasa, ketut.widiartini\}@pasca.undiksha.ac.id\}

\begin{abstract}
Abstrak
Penelitian ini bertujuan untuk mengetahui pengaruh penerapan model pembelajaran kooperatif tipe STAD dan bentuk asesmen kinerja terhadap keterampilan proses TIK. Sampel diambil dengan cara random dengan anggota sampel 147 orang. Rancangan dalam penelitian ini adalah post-test only control group. Data dianalisis dengan analisis varians (Anava) dua jalan dan uji Scheffe sebagai uji lanjut dan ditemukan hasil sebagai berikut. (1) Terdapat perbedaan yang signifikan antara keterampilan proses TIK siswa yang mengikuti model pembelajaran kooperatif tipe STAD dengan siswa yang mengikuti model pembelajaran konvensional; (2) Terdapat perbedaan yang signifikan antara keterampilan proses TIK siswa yang diberikan asesmen kinerja dengan siswa yang diberikan asesmen esai; (3) Terdapat pengaruh interaksi yang signifikan antara model pembelajaran dengan bentuk asesmen terhadap keterampilan proses TIK; (4) Keterampilan proses TIK siswa yang diberikan asesmen kinerja pada siswa yang mengikuti model pembelajaran kooperatif tipe STAD lebih tinggi daripada siswa yang mengikuti model pembelajaran konvensional; (5) Keterampilan proses TIK siswa yang diberikan asesmen esai pada siswa yang mengikuti model pembelajaran konvensional lebih tinggi daripada siswa yang mengikuti model pembelajaran kooperatif tipe STAD; (6) Keterampilan proses TIK siswa yang mengikuti model pembelajaran kooperatif tipe STAD pada siswa yang diberikan asesmen kinerja lebih tinggi daripada siswa yang diberikan asesmen esai; (7) Keterampilan proses TIK siswa yang mengikuti model pembelajaran konvensional pada siswa yang diberikan asesmen esai lebih tinggi daripada siswa yang diberikan asesmen kinerja.
\end{abstract}

Kata-kata kunci: asesmen, keterampilan proses TIK, STAD

\begin{abstract}
This study aims to determine the effect of application of cooperative learning model of STAD and performance assessment of ICT process skills. The sample was taken randomly with a sample of 147 people. This research was designed by performing post-test only control group. The ICT process skill data is collected through a process skill test. Data were analyzed by two-way variance analysis (Anava) and Scheffe test as post-hoc test and the results revealed that: (1) There are significant differences between the ICT skills of students who follow the model of STAD cooperative learning with students who follow the conventional learning model; (2) There is a significant difference between the ICT process skill of the students who performed the performance assessment and the students performed the essay assessment; (3) There is a significant interaction effect between the learning model and the
\end{abstract}




\begin{abstract}
assessment of ICT process skills; (4) The ICT process skills of the students who applied performance assessment on the STAD cooperative learning model is higher than the students who implemented the conventional learning model; (5) The ICT process skills of the students who applied essay assessment on the conventional learning model is higher than the students who implemented the STAD cooperative learning model;(6) The ICT process skills of the students who perfomed the model of STAD cooperative learning on the performance assessment is higher than the students who performed the essay assessment; (7) The ICT process skills of the students who perfomed the model of conventional learning on the essay assessment is higher than the students who performed the performance assessment.
\end{abstract}

Keywords: assessment, ICT process skills, cooperative learning model of STAD

\section{PENDAHULUAN}

Dalam era globalisasi, peningkatan mutu sumber daya manusia sangat penting. Hal ini dapat diwujudkan dengan meningkatkan mutu pendidikan. Di Indonesia masalah pendidikan sudah mendapat perhatian yang sangat serius oleh pemerintah. Inovasi - inovasi di bidang pengembangan mutu pendidikan telah dilakukan pemerintah untuk memperbaiki mutu pendidikan. Adapun perbaikan itu diantaranya adalah melaksanakan desentralisasi pendidikan, penyempurnaan kurikulum, perbaikan manajemen sekolah, peningkatan mutu guru dan tenaga kependidikan lainnya, serta pengadaan fasilitas penunjang lainnya.

Pendidikan yang bermutu merupakan syarat pokok untuk peningkatan mutu sumber daya manusia dalam memasuki era kesejagatan. Di samping itu perlu dikembangkan kesadaran bersama bahwa : (1) komitmen peningkatan mutu pendidikan merupakan bagian dari upaya untuk meningkatkan mutu sumber daya manusia, baik sebagai pribadi maupun sebagai modal dasar pembangunan bangsa, pemerataan daya tampung pendidikan harus disertai pemerataan mutu pendidikan, sehingga menjangkau seluruh masyarakat (Depdiknas, 2003).

Mata pelajaran Teknologi Informasi dan Komunikasi (TIK) sebagai salah satu mata pelajaran yang memerlukan daya kritis siswa dan pemahaman secara cermat, serta perhitungan-perhitungan yang membutuhkan logika dan ketelitian perlu mendapat perhatian khusus. Mata pelajaran Teknologi Informasi dan Komunikasi dimaksudkan untuk mempersiapkan peserta didik agar mampu mengantisipasi pesatnya perkembangan IPTEK (ilmu pengetahuan dan teknologi). Mata pelajaran ini perlu diperkenalkan, dipraktikkan dan dikuasai peserta didik sedini mungkin agar mereka memiliki bekal untuk menyesuaikan diri dalam kehidupan global yang ditandai dengan perubahan yang sangat cepat. Untuk menghadapi perubahan tersebut diperlukan kemampuan dan kemauan belajar sepanjang hayat dengan cepat dan cerdas. Hasil-hasil teknologi informasi dan komunikasi banyak membantu manusia untuk dapat belajar secara cepat.

Pendidikan TIK sebagai bagian dari materi pendidikan formal seharusnya mampu memberikan konstribusi bagi pembangunan sumber daya manusia yang berkualitas. Pendidikan TIK hingga saat ini masih belum menunjukkan hasil yang memuaskan. Meskipun TIK sudah diperkenalkan secara khusus di pendidikan dasar SMP, namun hasil belajar TIK di tingkat pendidikan menengah belum menunjukkan hasil seperti yang diharapkan. Banyak permasalahan ditemukan dalam pelajaran TIK di lapangan, seperti saranaprasarana yang kurang mendukung, kurangnya minat, bakat, dan motivasi siswa dalam mengikuti pembelajaran, suasana belajar yang kurang nyaman. sehingga kurang terciptanya pembelajaran yang efektif.

Pada proses pembelajaran TIK akan diarahkan pada penguasaan pengetahuan dan keterampilan proses TIK. Dengan belajar TIK diharapkan menjadi individu yang memiliki sikap ilmiah (jujur, objektif, terbuka, ulet dan dapat bekerja sama) serta mampu menggunakan pengetahuan TIK secara tepat dan bertanggungjawab. Maka dari itu mata pelajaran TIK perlu diperkenalkan, dipraktikkan dan dikuasai peserta didik sedini mungkin agar mereka 
memiliki bekal untuk menyesuaikan diri dalam kehidupan global yang ditandai dengan perubahan yang sangat cepat. Untuk menghadapi perubahan tersebut diperlukan kemampuan dan kemauan untuk belajar sepanjang hayat. Disamping itu dalam mata pelajaran TIK terdapat konsepkonsep teoritis yang membutuhkan pemahaman secara cermat, dan perhitungan-perhitungan yang membutuhkan logika dan ketelitian. Dengan demikian pendidikan perlu disesuaikan dengan tuntutan dan kebutuhan kehidupan.

Menurut Sumadi (1995), faktor internal dan eksternal siswa sangat menentukan dalam pencapaian keterampilan proses siswa. Salah satu faktor internal siswa yang berpengaruh terhadap keterampilan proses adalah motivasi intrinsik. Tiadanya motivasi yang berasal dari dalam diri siswa menyebabkan kesulitan - kesulitan yang dihadapi siswa sering tidak dicarikan solusi pemecahannya dan siswa menjadi kurang semangat dalam belajarnya. Kurangnya motivasi yang datang dari dalam diri siswa menyebabkan siswa akan mudah berputus asa dan belajarnya menjadi kurang terprogram dan terarah serta kurang bermakna.

Santyasa (2001:2) menyatakan bahwa, pembelajaran yang dilaksanakan selama ini kebanyakan bersifat tradisional yaitu guru mendominasi kegiatan belajar mengajar di kelas, misalnya guru lebih banyak menerapkan metode ceramah agar semua materi/bahan ajar dapat disampaikan dalam waktu yang relatif singkat. Pengajaran masih dipandang sebagai transfer pengetahuan, belum sebagai pembangun pengetahuan, keterampilan proses, dan sikap sains. Siswa dianggap belum mengetahui pelajaran yang diberikan oleh gurunya. Akibatnya guru akan selalu berceramah pada saat memberikan pelajaran, sehingga pembelajaran berpusat pada guru bukan berpusat pada siswa. Salah satu alasan para guru adalah sangat sulit mengekplorasi pengetahuan awal siswa. Para guru cenderung merancang dan mengimplementasikan pembelajaran dengan pola mengajar secara linier (Santyasa,2005).

Kondisi yang demikian, juga terjadi pada pembelajaran TIK di SMP Negeri 1
Kuta. Dari hasil supervisi yang dilakukan menunjukkan bahwa secara umum di lapangan dengan didukung juga dari hasil observasi awal, kebanyakan kesulitan guru dalam pembelajaran TIK terletak pada pengkondisian proses pembelajaran, dan hal ini terkait erat dengan pemilihan model pembelajaran dan pemilihan asesmen yang tepat. Fakta di sekolah berdasarkan hasil studi pendahuluan yang dilakukan pada guru-guru TIK di SMP Negeri 1 Kuta mengenai penerapan model pembelajaran inovatif diperoleh bahwa: (1) Seluruh guru belum mampu menggunakan model pembelajaran inovatif secara tepat sesuai dengan kondisi di kelas; (2) sebanyak 55\% guru merasa kesulitan dalam menerapkan model pembelajaran inovatif di kelas; (3) sebanyak $15 \%$ guru tidak memahami mengenai pembelajaran inovatif dan memilih untuk melakukan pembelajaran konvensional. Kemudian untuk penerapan asesmen autentik diperoleh bahwa: (1) Seluruh guru belum pernah dan merasa bingung untuk membuat instrumen penilaian hasil belajar sesuai dengan penggunaan asesmen autentik; (2) sebanyak $67 \%$ guru merasa kesulitan dalam membuat instrumen penilaian; (3) sebanyak $30 \%$ guru tidak memahami mengenai asesmen autentik dan memilih untuk melakukan penilaian tes ulangan dan menilai hasil kerja dalam praktik saja.

Dalam hubungannya dengan permasalahan di atas, maka untuk meningkatkan keterampilan proses TIK khususnya mata pelajaran TIK, alternatif tindakan yang dapat dilakukan adalah menerapkan model pembelajaran yang memungkinkan pembelajaran yang berpusat pada siswa. Berdasarkan hal tersebut, perlu adanya suatu model pembelajaran yang dapat menumbuhkan kegairahan belajar peserta didik, meningkatkan sikap ilmiah, motivasi belajar, kerjasama, saling belajar, keakraban, saling menghargai, dan partisipasi peserta didik.

Dalam model pembelajaran kooperatif tipe STAD ada beberapa langkah yang harus dilakukan yaitu: (1) guru mempresentasikan materi yang akan dipelajari secara garis besar dan prosedur kegiatan, juga tata cara kerja kelompok, (2) membentuk kelompok heterogen 
berdasarkan kemampuan akademis, jenis kelamin, ras, suku yang beranggotakan 4-5 orang, (3) siswa bekerja dalam kelompok, diskusi atau mengerjakan tugas sesuai dengan LKS, (4) guru memberikan bimbingan, (5) guru memberikan validasi hasil kerja kelompok dan memberikan kesimpulan tugas kelompok, (6) guru memberikan kuis secara individu, (7) penghargaan kelompok berdasarkan skor perhitungan yang diperoleh anggota, diratarata, hasilnya disesuaikan dengan predikat tim dan (8) evaluasi.

STAD merupakan salah contoh model pembelajaran kooperatif, sangat tepat bila menggunakan asesmen otentik sebagai basisnya karena asesmen otentik adalah asesmen yang meminta siswa untuk melakukan tugas-tugas nyata yang mewakili atau menunjukkan aplikasi secara bermakna atas pengetahuan dan keterampilan yang dimilikinya. Suatu pembelajaran kontekstual membutuhkan penilaian yang jelas. Artinya, perlu disusun seperangkat evaluasi keterlaksanaan pembelajaran kontekstual, instrumen serta teknik penilaian yang tepat. Salah satu asesmen otentik yang perlu dilakukan pada pembelajaran TIK adalah asesmen kinerja. Dantes (2008) mendefinisikan asesmen kinerja adalah penelusuran produk dan proses, artinya hasil-hasil kerja yang ditunjukkan dalam proses pelaksanaan program itu digunakan sebagai basis untuk dilakukan suatu pemantauan mengenai perkembangan dari satu pencapaian program tersebut. Hal ini senada dengan pengertian yang menyatakan asesmen kinerja adalah penilaian terhadap aktivitas siswa sebagaimana yang terjadi, terhadap unjuk kerja, tingkah laku atau interaksi siswa (Depdiknas, 2006).

Berdasarkan pendapat di atas dapat disimpulkan bahwa asesmen kinerja merupakan penilaian menyeluruh dari proses pembelajaran yang meliputi proses dan hasil belajar seperti unjuk kerja, hasil kerja, hasil belajar dan interaksi siswa. Alasan dari penggunaan asesmen kinerja didasarkan atas empat asumsi pokok yaitu (1) asesmen kinerja didasarkan partisipasi aktif siswa, (2) tugas-tugas yang diberikan atau dikerjakan siswa merupakan bagian yang tidak terpisahkan dari keseluruhan proses pembelajaran. (3) asesmen tidak hanya untuk mengetahui posisi siswa, tetapi untuk memperbaiki proses pembelajaran itu sendiri dan (4) dengan mengetahui lebih dahulu kreteria yang akan digunakan untuk mengukur dan menilai keberhasilan proses pembelajaran, siswa akan secara terbuka dan aktif untuk mencapai tujuan pembelajaran (Asmawi, 2001).

\section{METODE PENELITIAN}

Penelitian eksperimen ini adalah kuasi eksperimen (eksperimen semu). Rancangan eksperimen yang digunakan dalam penelitian ini adalah Two Factor Experiment. Rancangan analisis penelitian adalah desain faktorial $2 \times 2$. Dalam penelitian ini terdapat tiga variabel yang terdiri dari dua variabel bebas dan satu variabel terikat. Variabel bebas pertama adalah model pembelajaran (A) sebagai variabel perlakuan, variabel bebas kedua adalah penerapan asesmen (B) sebagai variabel moderator. Variabel terikat adalah keterampilan proses TIK (Y).. Populasi penelitian ini adalah seluruh siswa kelas VIII SMP Negeri 1 Kuta Tahun Pelajaran 2016/2017. Jumlah anggota populasi sebanyak 294 orang (2 kelas unggulan dan 6 kelas paralel).

Pengambilan sampel penelitian ini dilakukan dengan teknik random sampling. Langkah-langkah penentuan sampel adalah sebagai berikut. Pada tahap pertama keenam kelas paralel dilakukan uji kesetaraan dengan menganalisis rata-rata nilai raport semester ganjil mata pelajaran TIK dengan uji-t. Pada tahap kedua dipilih pasangan kelas sebagai kelas eksperimen dan sebagai kelas kontrol secara acak dengan teknik undian. Berdasarkan hasil undian diperoleh pasangan kelas $\mathrm{VIII}_{\mathrm{D}}$ dan VIII ${ }_{E}$ sebagai kelas eksperimen sebanyak 74 siswa dan pasangan kelas $\mathrm{VIII}_{G}$ dan $\mathrm{VIII}_{\mathrm{H}}$ sebagai kelas kontrol sebanyak 73 siswa.

Pengumpulan data dalam penelitian ini dengan tahapan sebagai berikut. (1) Pembuatan jadwal penelitian dengan mempertimbangkan jumlah jam mata pelajaran TIK per kelas, per minggu dan jadwal pelajaran siswa di kelas eksperimen maupun kontrol, (2) Untuk mengetahui keterampilan proses TIK digunakan 
penerapan asesmen kinerja dan asesmen esai, (3) Pemberian tes keterampilan proses TIK kepada kelompok kelas eksperimen dan kelompok kelas kontrol, data yang diperoleh berupa data interval.

Instrumen dalam penelitian berupa tes keterampilan proses TIK. Sebelum instrumen digunakan dilakukan uji validitas isi (content validity) dikonsultasikan kepada para pakar untuk dilakukan penilaian. Selanjutnya instrumen yang disusun dilakukan uji coba empiris kepada siswa kelas IX SMP Negeri 1 Kuta tahun ajaran 2016/2017 untuk menentukan validitas butir, dan reliabilitas tes. Untuk tes keterampilan proses TIK diujicobakan kepada 72 siswa kelas IX, selanjutnya validitas butir tes diuji dengan korelasi product moment $\left(r_{x y}\right)$ diperoleh 9 butir soal valid dari 10 soal, sedang uji reliabilitas tes dihitung dengan rumus Alpha Cronbach diperoleh koefisien reliabilitas sebesar $=0,809$.

Sebelum data dianalisis, dilakukan uji prasyarat. Anava dua jalan mempersyaratkan dua hal yaitu skor pada setiap sel harus berdistribusi normal dan varian skor pada setiap sel harus homogen, hasil perhitungan anava dua jalur dilakukan dengan bantuan Microsoft Excel 2013 dan SPSS 16,00 for windows. Uji normalitas sebaran data menggunakan teknik Lilliefors (Candiasa 2010:228), hasil uji teknik Lilliefors menyatakan semua kelompok data berdistribusi normal dan uji homogenitas kelompok varians digunakan uji Bartlett (Candiasa, 2010:278). Hasil Uji Bartlett menyatakan semua kelompok varian berasal dari populasi yang homogen.

Pengujian hipotesis dalam penelitian ini menggunakan analisis varians (ANAVA) dua jalan dan uji Scheffe. Pengujian hipotesis pertama, kedua, dan ketiga menggunakan anava dua jalan dengan uji $F$ pada taraf signifikan $5 \% \quad(\alpha=0,05)$, sedangkan pengujian hipotesis keempat sampai dengan pengujian hipotesis ketujuh dengan uji Scheffe pada taraf signifikan 5\% $(\alpha=0,05)$

\section{HASIL DAN PEMBAHASAN}

Tabel 1. Rekapitulasi Deskristif Statistik Masing-Masing Variabel

\begin{tabular}{|c|c|c|c|c|c|c|c|c|}
\hline Variabel Statistik & $\mathbf{A}_{1}$ & $A_{2}$ & $\mathrm{~B}_{1}$ & $\mathrm{~B}_{2}$ & $A_{1} B_{1}$ & $A_{1} B_{2}$ & $A_{2} B_{1}$ & $A_{2} B_{2}$ \\
\hline Mean & 28,62 & 27,00 & 29,14 & 26,48 & 31,84 & 25,41 & 26,43 & 27,58 \\
\hline Median & 29 & 27 & 30 & 26 & 32 & 25 & 26 & 27 \\
\hline Modus & 30 & 26 & 30 & 25 & 30 & 25 & 24 & 28 \\
\hline Standar Deviasi & 4,18 & 3,26 & 3,91 & 3,25 & 2,52 & 2,80 & 3,11 & 3,35 \\
\hline Varians & 17,50 & 10,61 & 15,30 & 10,59 & 6,36 & 7,86 & 9,64 & 11,22 \\
\hline Rentangan & 18 & 14 & 15 & 17 & 11 & 13 & 13 & 14 \\
\hline Skor minimum & 18 & 21 & 21 & 18 & 25 & 18 & 21 & 21 \\
\hline Skor maksimum & 36 & 35 & 36 & 35 & 36 & 31 & 34 & 35 \\
\hline Jumlah & 2118 & 1971 & 2156 & 1933 & 1178 & 940 & 978 & 993 \\
\hline
\end{tabular}


Pengujian hipotesis secara keseluruhan dengan menggunakan analisis varian (ANAVA) dua jalan, dapat disajikan dalam Tabel 2. berikut.

Tabel 2. Ringkasan ANAVA Dua Jalur

\begin{tabular}{|ccccccc|}
\hline Sumber Variasi & JK & db & RJK & $\mathbf{F}_{\text {(Hitung) }}$ & $\mathbf{F}_{\text {(Tabel:0.05) }}$ & Interpretasi \\
\hline Antar A & 96,64 & 1 & 96,64 & 11,04 & 3,94 & Signifikan \\
\hline Antar B & 259,17 & 1 & 259,17 & 29,61 & 3,94 & Signifikan \\
\hline Inter AB & 530,46 & 1 & 530,46 & 60,60 & 3,94 & Signifikan \\
\hline Dalam & $1.251,78$ & 143 & 8,75 & & & \\
\hline Total & $2.138,04$ & 146 & & & & \\
\hline
\end{tabular}

Uji hipotesis pertama, Hasil perhitungan dengan analisis varians (ANAVA) dua jalan menghasilkan nilai $F_{(A)}$ hitung $=11,039$, sedangkan harga $F_{(A)}$ tabel untuk $\mathrm{db}_{\mathrm{A}}=1$ dan $\mathrm{db}_{\mathrm{D}}=143$ pada tarap signifikan 3,94 pada taraf kepercayaan 0,05 . Ternyata $F_{(A)}$ hitung lebih besar daripada $F_{(A)}$ tabel $\left(F_{(A)}\right.$ hitung $\left.=11,039>F_{(0,05)(1: 143)}=3,94\right)$. Ini berarti hipotesis nol $\left(\mathrm{H}_{\circ}\right)$ ditolak. Sehingga dapat disimpulkan bahwa terdapat perbedaan keterampilan proses TIK antara siswa yang mengikuti model pembelajaran kooperatif tipe STAD dengan siswa yang mengikuti model pembelajaran konvensional. Dimana keterampilan proses TIK pada siswa yang mengikuti model pembelajaran kooperatif tipe STAD memiliki skor rata-rata sebesar 28,62 sedangkan kelompok siswa yang mengikuti model pembelajaran konvensional memiliki skor rata-rata keterampilan proses TIK sebesar 27,00. Secara keseluruhan, keterampilan proses TIK siswa yang mengikuti model pembelajaran kooperatif tipe STAD lebih tinggi daripada keterampilan proses TIK siswa yang mengikuti model pembelajaran konvensional pada siswa kelas VIII SMP Negeri 1 Kuta. Hal ini disebabkan siswa lebih banyak dilibatkan dalam kegiatan pembelajaran kooperatif tipe STAD. Dalam pembelajaran kooperatif tipe STAD yang berbasis kelompok, siswa satu dengan siswa lainnya saling berinteraksi. Siswa yang pandai akan memberi dorongan kepada temannya yang memiliki kemampuan kurang, begitu pula sebaliknya siswa yang belum paham akan lebih mudah bertanya dengan teman sejawatnya mengenai materi yang belum dipahami.
Melalui model pembelajaran ini siswa akan mampu membangun sendiri pengetahuannya, dengan demikian apa yang mereka pelajari tentang TIK akan lebih mudah dipahami dan bermakna, sehingga keterampilan proses TIK siswa dapat meningkat.

Sedangkan model pembelajaran konvensional merupakan pembelajaran yang lazim dilakukan pada kegiatan pembelajaran rutinitas sehari - hari. Arah penyampaian informasi ini hanya terjadi satu arah saja dan tidak pernah dua arah. Siswa dianggap belum mengetahui pelajaran yang diberikan oleh gurunya. Akibatnya guru akan selalu berceramah pada saat memberikan pelajaran, sehingga pembelajaran berpusat pada guru bukan berpusat pada siswa. Akibat dari pembelajaran tersebut siswa menjadi terbiasa menerima apa saja yang diberikan oleh guru tanpa mau menemukan sendiri konsep-konsep yang sedang dipelajari. Pembelajaran dengan model belajar konvensional akan bisa mengakibatkan pengetahuan yang dimiliki siswa akan terbatas apa yang diberikan guru. Metode pembelajaran yang berorientasi pada kemampuan guru (teacher centered) tentu akan menghasilkan hasil belajar yang berbeda dengan metode pembelajaran yang berorientasi pada siswa (student centered).

Uji hipotesis kedua menunjukkan bahwa dari perhitungan dengan analisis varians (ANAVA) dua jalan menghasilkan nilai $F_{(B)}$ hitung $=29,607$, sedangkan harga $F_{(B)}$ tabel untuk $\mathrm{db}_{\mathrm{B}}=1$ dan $\mathrm{db}_{\mathrm{D}}=92$ pada tarap signifikan 3,94 pada taraf 
kepercayaan 0,05 . Ternyata $F_{(B)}$ hitung lebih besar daripada $F_{(B)}$ tabel $\left(F_{(A) \text { hitung }}=29,607\right.$ $\left.>F_{(0,05)(1: 143)}=3,94\right)$. Ini berarti hipotesis nul $\left(\mathrm{H}_{\circ}\right)$ ditolak. Sehingga dapat disimpulkan bahwa terdapat perbedaan keterampilan proses TIK antara siswa yang diberikan asesmen kinerja dengan siswa yang diberikan asesmen esai. Dimana keterampilan proses TIK pada siswa yang diberikan asesmen kinerja memiliki skor rata-rata sebesar 29,14 sedangkan kelompok siswa yang diberikan asesmen esai memiliki skor rata-rata keterampilan proses TIK sebesar 26,48. Secara keseluruhan, keterampilan proses TIK siswa yang diberikan asesmen kinerja lebih tinggi daripada keterampilan proses TIK siswa yang diberikan asesmen esai pada siswa kelas VIII SMP Negeri 1 Kuta. Hal ini disebabkan karena asesmen kinerja merupakan penilaian menyeluruh dari proses pembelajaran yang meliputi proses dan hasil belajar seperti unjuk kerja, hasil kerja, hasil belajar dan interaksi siswa. Kelebihan dari asesmen kinerja adalah dapat mengetahui hasil belajar yang kompleks dan keterampilan - keterampilan yang tidak dapat dievaluasi dengan tes tradisional (paper and pencil test), dengan demikian apa di evaluasi akan lebih mudah diukur. Sedangkan asesmen esai merupakan penilaian yang pemberian skornya sering dipengaruhi oleh opini atau penilaian dari pendidik atau pemeriksa tes tersebut. Jenis tes esai menghendaki peserta didik untuk mengorganisasikan, merumuskan, dan mengemukakan sendiri jawabannya.

Uji hipotesis ketiga menunjukkan bahwa dari perhitungan dengan analisis varians (ANAVA) dua jalan menghasilkan nilai $F_{A \times B}$ hitung $=60,598$ dan harga $F$ tabel pada $\mathrm{dk}_{\mathrm{A}}=1, \mathrm{dk}_{\mathrm{D}}=143$, $\alpha=0,05$ sebesar 3,94. Hal ini berarti nilai $F_{A \times B}$ hitung lebih besar daripada nilai $F_{\text {tabel }}$ pada taraf signifikansi $5 \%\left(F_{\text {AxB hitung }}=60,598>F_{\text {tabel }}=\right.$ $3,94)$. Ini berarti hipotesis nul $\left(\mathrm{H}_{\mathrm{o}}\right)$ ditolak. Sehingga dapat disimpulkan bahwa terdapat pengaruh interaksi antara model pembelajaran dengan asesmen terhadap keterampilan proses TIK. Hal ini disebabkan karena dalam model pembelajaran kooperatif tipe STAD menekankan pada pemberian kesempatan belajar yang lebih luas dan suasana yang kondusif kepada siswa untuk mengembangkan sikap ilmiah, nilai dan keterampilan sosial yang bermanfaat bagi kehidupan masyarakat. Pada model pembelajaran konvensional siswa diberikan sedikit kesempatan untuk mengembangkan kemampuan dan ide atau gagasan dalam memecahkan masalah. Siswa lebih banyak dituntut untuk menghafalkan fakta, prinsip atau teori saja. Selain itu model pembelajaran konvensional lebih menekankan kemampuan guru dalam menyampaikan pelajaran. Pelajaran diuraikan secara rinci dari satu topik ke topik yang lain secara mendetail. Selanjutnya untuk setiap model pembelajaran yang digunakan, asesmen merupakan tahap akhir dari suatu pembelajaran sangat penting peranannya. Dikatakan demikian karena asesmen minimal dapat menghasilkan dua hal yaitu : pertama, sebagai umpan balik pada proses pembelajaran, dan kedua, dapat memberikan informasi mengenai kualitas perolehan pada subyek didik. Hasil penelitian yang diperoleh telah sesuai dengan teori yang ada dan sesuai dengan hasil penelitian yang dilakukan oleh Virnayanthi (2012) yang menyatakan terdapat pengaruh interaksi antara model pembelajaran dengan asesmen.

Uji hipotesis keempat menunjukkan bahwa kelompok siswa yang diberikan asesmen kinerja dengan penerapan model pembelajaran kooperatif tipe STAD $\left(A_{1} B_{1}\right)$ memiliki skor rata-rata keterampilan proses TIK sebesar 31,84 sedangkan kelompok siswa yang diberikan asesmen kinerja dengan penerapan model pembelajaran konvensional $\left(A_{2} B_{1}\right)$ memiliki skor rata-rata keterampilan proses TIK sebesar 26,43. Sementara itu, hasil perhitungan ANAVA dua jalan menunjukkan bahwa rata-rata jumlah kuadrat dalam (RKD) sebesar 8,754. Berdasarkan hasil uji Scheffe diperoleh $t_{\text {hitung }}$ sebesar 61,750 , sedangkan $t_{\text {tabel }}$ pada taraf signifikansi 0,05 sebesar 2,70. Dari hasil uji Scheffe menunjukkan nilai $t_{\text {hitung }}$ lebih besar daripada $t_{\text {tabel }}$ ( $t_{\text {hitung }}=61,750>$ $\left.t_{\text {tabel }}=2,70\right)$. Hal ini berarti hipotesis nul $\left(\mathrm{H}_{0}\right)$ ditolak. Jadi dapat disimpulkan bahwa Pada siswa yang diberikan asesmen kinerja, terdapat perbedaan data keterampilan 
proses TIK siswa yang mengikuti model pembelajaran kooperatif tipe STAD dengan siswa yang mengikuti model pembelajaran konvensional. Dimana keterampilan proses TIK siswa yang mengikuti model pembelajaran kooperatif tipe STAD lebih baik daripada keterampilan proses TIK siswa yang mengikuti model pembelajaran konvensional pada siswa yang diberikan asesmen kinerja. Hal ini sesuai dengan hasil penelitian yang dilakukan oleh Wartika (2014) dan Mariani (2014) dimana pada penelitian mereka sama-sama menyatakan bahwa pada siswa yang diberikan asesmen kinerja dengan penerapan model pembelajaran kooperatif tipe STAD lebih baik dibandingkan model pembelajaran konvensional.

Uji hipotesis kelima menunjukkan bahwa kelompok siswa yang diberikan asesmen esai dengan penerapan model pembelajaran kooperatif tipe STAD $\left(A_{1} B_{2}\right)$ memiliki skor rata-rata keterampilan proses TIK sebesar 25,41 sedangkan kelompok siswa yang diberikan asesmen esai dengan penerapan model pembelajaran konvensional $\left(\mathrm{A}_{2} \mathrm{~B}_{2}\right)$ memiliki skor rata-rata keterampilan proses TIK sebesar 27,58. Sementara itu, hasil perhitungan ANAVA dua jalan menunjukkan bahwa rata-rata jumlah kuadrat dalam (RKD) sebesar 8,754. Berdasarkan hasil uji Scheffe diperoleh $t_{\text {hitung }}$ sebesar 9,887 , sedangkan $t_{\text {tabel }}$ pada taraf signifikansi 0,05 sebesar 2,70. Dari hasil uji Scheffe menunjukkan nilai $t_{\text {hitung }}$ lebih besar daripada $t_{\text {tabel }}\left(\mathrm{t}_{\text {hitung }}=9,887>\right.$ $\left.t_{\text {tabel }}=2,70\right)$. Hal ini berarti hipotesis nol $\left(\mathrm{H}_{0}\right)$ ditolak. Jadi dapat disimpulkan bahwa pada siswa yang diberikan asesmen esai, terdapat perbedaan data keterampilan proses TIK siswa yang mengikuti model pembelajaran kooperatif tipe STAD dengan siswa yang mengikuti model pembelajaran konvensional. Dimana keterampilan proses TIK siswa yang mengikuti model pembelajaran konvensional lebih baik daripada keterampilan proses TIK siswa yang mengikuti model pembelajaran kooperatif tipe STAD pada siswa yang diberikan asesmen esai. Hal ini sesuai dengan hasil penelitian yang diperoleh dengan teori yang ada dan sesuai dengan hasil penelitian yang dilakukan oleh Hidayat
(2012) dan Virnayanthi (2012) dimana pada penelitian mereka sama-sama menyatakan bahwa pada siswa yang diberikan asesmen esai dengan penerapan model pembelajaran konvensional lebih baik dibandingkan model pembelajaran kooperatif tipe STAD.

Uji hipotesis keenam menunjukkan bahwa kelompok siswa yang mengikuti model pembelajaraan kooperatif tipe STAD dengan diberikan penerapan asesmen kinerja $\left(A_{1} B_{1}\right)$ memiliki skor rata-rata keterampilan proses TIK sebesar 31,84 sedangkan kelompok siswa yang mengikuti model pembelajaraan kooperatif tipe STAD dengan diberikan penerapan asesmen esai $\left(A_{1} B_{2}\right)$ memiliki skor rata-rata keterampilan proses TIK sebesar 25,41. Sementara itu, hasil perhitungan ANAVA dua jalan menunjukkan bahwa rata-rata jumlah kuadrat dalam (RKD) sebesar 8,754. Berdasarkan hasil uji Scheffe diperoleh $t_{\text {hitung }}$ sebesar 9,887 , sedangkan $t_{\text {tabel }}$ pada taraf signifikansi 0,05 sebesar 2,70. Dari hasil uji Scheffe menunjukkan nilai $t_{\text {hitung }}$ lebih besar daripada $\mathrm{t}_{\text {tabel }}\left(\mathrm{t}_{\text {hitung }}=9,887>\right.$ $\left.t_{\text {tabel }}=2,70\right)$. Hal ini berarti hipotesis nol $\left(\mathrm{H}_{0}\right)$ ditolak. Jadi dapat disimpulkan bahwa pada siswa yang mengikuti model pembelajaran kooperatif tipe STAD, terdapat perbedaan data keterampilan proses TIK siswa yang diberikan asesmen kinerja dengan siswa yang diberikan asesmen esai. Dimana keterampilan proses TIK siswa yang mengikuti model pembelajaran kooperatif tipe STAD dan diberikan asesmen kinerja lebih baik daripada keterampilan proses TIK siswa yang diberikan asesmen esai. Hal ini karena model pembelajaran kooperatif tipe STAD cenderung lebih mampu menganalisis dan menghubungkan konsepkonsep yang relevan serta menggabungkan ke dalam rangkaian pemikiran yang nyata, memiliki kemampuan untuk mengidentifikasi fakta dan menemukan hubungan antar fakta dengan kehidupan sehari-hari. Sementara asesmen kinerja adalah dapat mengetahui hasil belajar yang kompleks dan keterampilan - keterampilan yang tidak dapat dievaluasi dengan tes tradisional (paper and pencil test), dengan demikian apa di evaluasi akan lebih mudah diukur dengan didukung model 
pembelajaran yang sesuai yaitu model pembelajaran kooperatif tipe STAD.

Uji hipotesis ketujuh menunjukkan bahwa kelompok siswa yang mengikuti model pembelajaran konvensional dengan diberikan penerapan asesmen kinerja $\left(A_{2} B_{1}\right)$ memiliki skor rata-rata keterampilan proses TIK sebesar 26,43 sedangkan kelompok siswa yang mengikuti model pembelajaraan konvensional dengan diberikan penerapan asesmen esai $\left(A_{2} B_{2}\right)$ memiliki skor rata-rata keterampilan proses TIK sebesar 27,58. Sementara itu, hasil perhitungan ANAVA dua jalan menunjukkan bahwa rata-rata jumlah kuadrat dalam (RKD) sebesar 8,754. Berdasarkan hasil uji Scheffe diperoleh thitung sebesar 2,761, sedangkan $t_{\text {tabel }}$ pada taraf signifikansi 0,05 sebesar 2,70. Dari hasil uji Scheffe menunjukkan nilai thitung lebih besar daripada $\mathrm{t}_{\text {tabel }}\left(\mathrm{t}_{\text {hitung }}=2,761>\mathrm{t}_{\text {tabel }}=2,70\right.$ ). $\mathrm{Hal}$ ini berarti hipotesis nol $\left(\mathrm{H}_{0}\right)$ ditolak. Jadi dapat disimpulkan bahwa pada siswa yang mengikuti model pembelajaran konvensional, terdapat perbedaan data keterampilan proses TIK siswa yang diberikan asesmen kinerja dengan siswa yang diberikan asesmen esai. Dimana keterampilan proses TIK siswa yang mengikuti model pembelajaran konvensional dan diberikan asesmen esai lebih baik daripada keterampilan proses TIK siswa yang diberikan asesmen kinerja pada siswa yang mengikuti model pembelajaran konvensional. Hal ini karena siswa yang terbiasa diberikan model pembelajaran konvensional cenderung lebih mudah melaksanakan asesmen esai dimana asesmen tersebut sudah biasa diterapkan dalan pembelajaran sehari-hari. Sementara asesmen kinerja adalah dapat mengetahui hasil belajar yang kompleks dan keterampilan - keterampilan yang tidak dapat dievaluasi dengan tes tradisional (paper and pencil test), dengan demikian apa di evaluasi akan lebih mudah diukur.

\section{SIMPULAN DAN SARAN}

Berdasarkan analisis dan pembahasan seperti yang telah dipaparkan pada bagian sebelumnya, dapat disimpulkan beberapa hal sebagai berikut.
Pertama, terdapat perbedaan keterampilan proses TIK antara siswa yang mengikuti model pembelajaran kooperatif tipe STAD dengan siswa yang mengikuti model pembelajaran konvensional pada siswa kelas VIII SMP Negeri 1 Kuta. Skor rata-rata keterampilan proses TIK yang mengikuti model pembelajaran kooperatif tipe STAD lebih tinggi daripada model pembelajaran konvensional.

Kedua, terdapat perbedaan keterampilan proses TIK antara siswa yang diberikan asesmen kinerja dengan siswa yang diberikan asesmen esai pada siswa kelas VIII SMP Negeri 1 Kuta. Skor ratarata keterampilan proses TIK yang diberikan asesmen kinerja lebih tinggi daripada yang diberikan asesmen esai.

Ketiga, terdapat pengaruh interaksi antara model pembelajaran dengan asesmen terhadap keterampilan proses TIK pada siswa kelas VIII SMP Negeri 1 Kuta.

Keempat, pada siswa yang diberikan asesmen kinerja, terdapat perbedaan keterampilan proses TIK antara siswa yang mengikuti model pembelajaran kooperatif tipe STAD dengan siswa yang mengikuti model pembelajaran konvensional. Dimana, pada siswa yang diberikan asesmen kinerja skor rata-rata keterampilan proses TIK siswa yang mengikuti model pembelajaran kooperatif tipe STAD lebih tinggi daripada siswa yang mengikuti model pembelajaran konvensional.

Kelima, pada siswa yang diberikan asesmen esai, terdapat perbedaan keterampilan proses TIK antara siswa yang mengikuti model pembelajaran kooperatif tipe STAD dengan siswa yang mengikuti model pembelajaran konvensional. Dimana, pada siswa yang diberikan asesmen esai skor rata-rata keterampilan proses TIK siswa yang mengikuti model pembelajaran konvensional lebih tinggi daripada siswa yang mengikuti model pembelajaran kooperatif tipe STAD.

Keenam, pada siswa yang mengikuti model pembelajaran kooperatif tipe STAD, terdapat perbedaan keterampilan proses TIK antara siswa yang diberikan asesmen kinerja dengan siswa yang diberikan asesmen esai. Dimana, pada siswa yang mengikuti model 
pembelajaran kooperatif tipe STAD skor rata-rata keterampilan proses TIK siswa yang diberikan asesmen kinerja lebih tinggi daripada siswa yang diberikan asesmen esai.

Ketujuh, pada siswa yang mengikuti model pembelajaran konvensional, terdapat perbedaan keterampilan proses TIK antara siswa yang diberikan asesmen kinerja dengan siswa yang diberikan asesmen esai. Dimana, pada siswa yang mengikuti model pembelajaran konvensional skor rata-rata keterampilan proses TIK siswa yang diberikan asesmen esai lebih tinggi daripada siswa yang diberikan asesmen kinerja.

Saran tampaknya penting untuk disampaikan terkait dengan temuan yang diperoleh pada penelitian ini adalah sebagai berikut. 1) Mengingat model pembelajaran kooperatif tipe STAD dan penerapan asesmen kinerja memiliki keunggulan komparatif terhadap model pembelajaran konvensional dalam meningkatkan keterampilan proses TIK siswa, maka diharapkan kepada para guru TIK agar menggunakan model pembejaran kooperatif tipe STAD dan asesmen kinerja untuk meningkatkan keterampilan proses TIK siswa., 2) Model pembelajaran kooperatif tipe STAD dan penerapan asesmen kinerja hendaknya lebih dikembangkan lagi secara kreatif dan inovatif, sehingga para guru tertantang untuk melakukan inovasi-inovasi baru dalam proses pembelajaran., 3) Model pembelajaran kooperatif tipe STAD dan penerapan asesmen kinerja telah terbukti dapat meningkatkan keterampilan proses TIK secara bermakna hendaknya terus diaplikasikan pada berbagai mata pelajaran yang relevan dengan model tersebut, 4) Para guru pemegang kebijakan di bidang pendidikan hendaknya menyebarluaskan temuan ini, sehingga dapat digunakan sebagai acuan di dalam pengembangan strategi pembelajaran inovatif.

\section{DAFTAR RUJUKAN}

Candiasa. 2010. Statistik Univariat dan Bivariat Disertai Aplikasi SPSS. Singaraja: Undiksha Press.
Dantes. 2008. Hakikat Asesmen Otentik Sebagai Penilaian Proses dan Produk dalam Pembelajaran yang Berbasis Kompetensi. Makalah disampaikan pada In House Traning (IHT) SMA Negeri 1 Kuta Utara tanggal 22 Mei 2008.

Depdiknas. 2003. Standar Kompetensi Mata Pelajaran Kimia Sekolah Menengah dan Madrasah Aliyah. Jakarta : Depdiknas.

Depdiknas. 2006. Panduan Pengembangan Materi Pembelajaran. Jakarta: Depdiknas Direktorat Jendral Manajemen Pendidikan Dasar dan Menengah Direktorat Pembinaan Sekolah Menengah Atas.

Marhaeni. 2008. Pembelajaran Berbasis Asesmen Otentik dalam Rangka Implementasi Sekolah Kategori Mandiri (SKM). Makalah, disajikan pada Pelatihan Peningkatan Kinerja Guru SMA 1 Kediri Tabanan, dalam Rangka Implementasi SKM, tanggal 30 Desember 2008.

Mariani. 2014. Pengaruh Implementasi Asesmen Kinerja Terhadap Hasil Belajar Membaca Bahasa Jepang Ditinjau dari Tingkat Kecemasan Belajar Siswa Kelas XI Akomodasi Perhotelan Pada SMK Negeri 1 Tegallalang. Tesis. Program Pasca Sarjana Undiksha Singaraja.

Parwata. 2008. Pengaruh Model Pembelajaran Kooperatif Teknik Tutor Sebaya Terhadap Kreativitas Dan Prestasi Belajar Matematika Siswa (Studi Eksperimen Pada Para Siswa Kelas X SMA Negeri I Payangan). Tesis. Program Pasca Sarjana Undiksha Singaraja.

Rusmayani dkk. 2013. Pengaruh Implementasi Asesmen Projek Terhadap Hasil Belajar Tik Dengan Kovariabel Kemampuan Numerik Dan Ekspektasi Karir Bidang Informatika (Studi Pada Siswa Kelas XI SMA Dharma Praja Badung) Tahun

Jurnal Penelitian dan Evaluasi Pendidikan | 98 
2013/2014. Jurnal Penelitian Program

Studi Penelitian dan Evaluasi

Pendidikan, Program Pascasarjana Universitas Pendidikan Ganesha

Singaraja, Indonesia.

Santyasa, I. W. 2001. Pengaruh Belajar Kooperatif dan Modul Pengajaran Kelompok Terhadap Hasil Belajar Siswa Kelas 1 SMUN 3 Singaraja. Usulan Penelitian (tidak diterbitkan). Jurusan Pendidikan Fisika, STKIP N Singaraja.

Santyasa. 2007. Belajar dan Pembelajaran. Bahan Buku Ajar Fakultas Pendidikan Jurusan Pendidikan Fisika. Singaraja : IKIP Institut Pendidikan Fisika.

Suirdja. 2009. Pengaruh Model Pembelajaran Keterampilan Proses Sosial Terhadap Pemahaman Konsep dan Sikap Sosial Siswa Kelas V Sekolah Dasar di Gugus IV Selemadeg Barat Kabupaten Tabanan. Tesis. Program Pasca Sarjana Undiksha Singaraja.

Virnayanthi. 2012. Pengaruh Model Pembelajaran Kooperatif Tipe Student Teams Achievement Divisions dan Bentuk Asesmen terhadap Prestasi Belajar Kewirausahaan pada Siswa Kelas XII SMK Negeri 1 Mas - Ubud. Tesis. Program Pasca Sarjana Undiksha Singaraja.

Wartika. 2014. Pengaruh Penerapan Model Pembelajaran Kooperatif Tipe STAD Berbasis Asesmen Kinerja Terhadap Hasil Belajar Fisika Ditinjau dari Sikap IImiah Siswa Kelas XI IPA SMA Negeri 1 Kuta. Tesis. Program Pasca Sarjana Undiksha Singarja 